\title{
Sharia Compliance in Sharia Mutual Funds: A Qualitative Approach
}

\author{
Submitted 14/04/19, $1^{\text {st }}$ revision 09/05/20, $2^{\text {nd }}$ revision 15/06/20, accepted 20/07/20 \\ Umi Widyastuti ${ }^{1}$, Erie Febrian ${ }^{2}$, Sutisna Sutisna ${ }^{3}$, Tettet Fitrijanti ${ }^{4}$
}

\begin{abstract}
:
Purpose: This study aims to describe the elements of Sharia compliance found in Sharia mutual funds, according to the fatwa of the National Sharia Board or Dewan Syariah Nasional (DSN) - the Indonesian Ulema Council or Majelis Ulama Indonesia (MUI) and some regulations which were issued by the Financial Services Authority or Otoritas Jasa Keuangan (OJK) in Indonesia.

Design/Methodology/Approach: This study applied a qualitative approach using documentary and secondary data including fatwa and regulations which are needed to explore the Sharia compliance of Sharia mutual funds. This study highlighted and identified the elements of Sharia compliance using a hierarchy map.

Findings: This study shows that Sharia mutual funds are Sharia compliant since they are obey Islamic principle including non-interest transaction, offering the halal product, no uncertainty (gharar) and no element of gambling. The OJK's regulation and fatwa from the DSN-MUI emphasised other Islamic principles, including the prohibition of margin trading, short selling, and insider trading in Sharia mutual fund investments. They permit to payment of compensation (ujrah) for the service which are provided by the investment managers.

Practical Implications: This study notes that economic activities (mu'amalah) should be conducted based on Islamic law. Due to the limited number of Islamic banks that being permitted to act as custodian banks in Indonesia, the mu'amalah of the Sharia mutual funds is conducted through conventional banks. This finding means the policymakers need to create more Islamic custodian banks for Sharia mutual fund investments.
\end{abstract}

Originality/Value: The study has a contribution in identifying the elements of Sharia compliance in Sharia mutual funds in Indonesia.

Keywords: Sharia compliance, Sharia mutual funds, Islamic principles.

JEL Code: K2, K19, K22.

Paper Type: Research study.

\footnotetext{
${ }^{1}$ Universitas Negeri Jakarta, umiwidyastutifeunj@unj.ac.id

${ }^{2}$ Universitas Padjadjaran, erie.febrian@unpad.ac.id

${ }^{3}$ Universitas Padjadjaran, sutisna_mmunpad@yahoo.com

${ }^{4}$ Universitas Padjadjaran, tettet.fitrijanti@unpad.ac.id
} 


\section{Introduction}

An expansion of Islamic finance has occurred over the last two decades (Jaballah, Peillex, and Weill, 2018). This also applies to the Islamic financial markets which have developed in almost every country (Suryanto and Thalassinos, 2017; Bernanthos, 2018; Hussain et al., 2018). According to Nurhisam (2016), one of the fundamental aspects that distinguish between Sharia and conventional financial industries is the existence of Islamic law, which reflects the Islamic principles' use for the guidance of activities in the economy. People who engage in an Islamic contract have to obey Islamic law. This is known as Sharia compliance. Therefore, one of the legal aspects that should be considered in the Sharia financial industry, including Sharia mutual funds, is the regulations or fatwa which are issued based on what is in the Holy Quran and the Hadith.

Dakhoir (2019) stated that fatwa are recognised as part of the Islamic law, which is recognised by Indonesia's legal systems. As stated in the OJK regulation number 19/POJK.04/2015 (OJK, 2015b), the Islamic principles applied to the financial market are the Islamic legal principles covering Sharia activities in financial markets, based on the fatwa issued by the DSN-MUI, as long as these fatwas did not contravene the OJK's regulations. These regulations and fatwa aid the investment manager when making investment decisions and ensure that each investment meets the requirements for Sharia compliance.

Besides, DeLorenzo (2000) stated that Muslim investors have been increasing in numbers. They expect their money to be managed by the professional investment managers without breaching Islamic principles. In fact, as noted by Widyastuti, Febrian, Sutisna, and Fitrijanti (2019), non-Sharia compliance maybe occur in Sharia mutual fund investments, while investors will react toward this risk by withdrawing their funds. Nowadays, investors have concerns about the importance of Sharia compliance for their investment. Nevertheless, only a limited number of articles are available about Sharia compliance in Sharia mutual funds. Therefore this is an interesting topic and should be discussed further. In this study, we explored the regulations of the Government of Indonesia (GoI), the fatwa issued about this subject, and we highlighted and identified the Islamic principles which are required for Sharia mutual funds. Based on the prior research, we believe that this study will contribute by describing the elements of Sharia compliance for Sharia mutual fund investments, based on the system found in Indonesia.

\section{Methodology}

This study applied the contextual approach in a qualitative study (Ritchie, Lewis, Nicholls, and Ormston, 2013). This approach is able to explore the elements of Sharia compliance in Indonesia. The data were obtained from several references, including the regulation and fatwa which are implemented for Sharia mutual fund investments. Therefore, the purpose of this study is to describe the elements of 
Sharia compliance, found in Sharia mutual funds, which refer to the fatwa of the DSN-MUI and the OJK's regulation. In Indonesia, the regulations and fatwa which are used by the investment manager as guidance in allocating the investor's funds are as follows:

$>$ The fatwa issued by the DSN-MUI number: 126/DSN-MUI/VII/2019 (Dewan Syariah Nasional, 2019);

> The fatwa issued by the DSN-MUI number: 40/DSN-MUI/X/2003 (Dewan Syariah Nasional, 2003);

$>$ The fatwa issued by the DSN-MUI number: 20/DSN-MUI/IV/2001 (Dewan Syariah Nasional, 2001);

$>$ The fatwa issued by the MUI number: 1 of 2004 (Majelis Ulama Indonesia, 2004);

$>$ The OJK regulation number: 15/POJK.04/2015 (OJK, 2015a);

$>$ The OJK regulation number: 19/POJK.04/2015 (OJK, 2015b);

$>$ The OJK regulation number: 35/POJK.04/2017 (OJK, 2017).

The secondary data were collected from documents published by the GoI, including the OJK's regulation, the fatwa issued by the DSN-MUI, the fatwa issued by the MUI, and articles published about Sharia compliance by several scholars. Data were categorised into some nodes using NVivo 10, subsequently, data were analysed using a hierarchy map to convey some nodes based on the number of items coded.

\section{Finding and Discussions}

The products which are offered in Sharia mutual funds have to meet Sharia compliant. The following section describes the elements of Sharia compliance found in Sharia mutual funds, based on the hierarchy map. Referring to these regulations and fatwa, the hierarchy map shows that the elements of Sharia compliance in Sharia mutual funds could be categorised as having the following principles.

\subsection{Non-Usury (Non-Interest) based Transaction}

This refers to the fatwa number 1 of 2004 (Majelis Ulama Indonesia, 2004), which states that interest or fa'idah is defined as "an additional charge in lending transactions (al-qardh) which is calculated from the principal, based on the maturity and with a certain percentage that is calculated in advance without considering the gain from this loan." Subsequently, it also explains the meaning of riba' or usury which occurs due to a delay in payment. This is called riba nasi'ah. Thus, compound interest is one form of usury, and it is a non-halal (haram) practices. This practice is forbidden in Islam, but it is commonly applied in insurance or financial markets, cooperatives and other financial institutions, or even by individuals.

The law about usury in Islam is clearly stated in the Holy Quran, Surah Al-Baqarah: 275 which states that 'Allah permits trading and forbids usury.' Therefore, Sharia 
mutual fund investment products are not permitted to contain any element of usury because this violates the Islamic principles explicitly stated in the Holy Quran. It is strengthened by the fatwa and OJK's regulations.

The fatwa DSN-MUI number 20/DSN-MUI/IV/2001 (Dewan Syariah Nasional, 2001) provides guidance for investment managers to manage Sharia mutual fund investments. One of the points concerns how to allocate the funds into certain financial products, especially when investing in Sharia stock mutual funds and money market investments. The Sharia stock mutual funds are dominated by some Islamic share, which can be called Islamic share if they comply with the financial and operational screening currently in place. This is also reinforced by the OJK regulation number 35/POJK.04/2017 (OJK, 2017) which explains that the shares could be categorised as an Islamic share through the screening in financing and operating activities. The financing screening is to check that a company does not use debt financing containing usury of more than 45 percent while the operating screening requires the company's interest revenue to be less than 10 percent of its total revenue.

OJK regulation number 15/POJK.04/2015 (OJK, 2015a) emphasises that conducting financial transactions with conventional financial services has to be avoided. When selecting the types of Sharia mutual fund investments, it is enabled for the investor to invest in Sharia mutual funds by choosing the mixture of Sharia mutual funds or the money market investments. The investor should be aware that Sharia compliance also has to be considered. In this context, the investment manager must follow Islamic law when selecting the Islamic bank which provides a time deposit as the component of financial instruments in the mixture of Sharia mutual funds and money market investments.

\subsection{Halal Products}

In the context of Sharia mutual fund investments, the investment manager has to allocate the funds to Islamic stocks. One of the criteria which is used to categorise a share as an Islamic stock is the company must offer the halal products. According to the OJK's regulation and fatwa issued by the DSN-MUI, a halal product is a product or a service that is produced or provided through business activities conducted in accordance with Islamic principles.

The types of businesses which are considered to be contrary to Islamic principles are mentioned in the DSN-MUI's fatwa number 20/DSN-MUI/IV/2001 (Dewan Syariah Nasional, 2001). They include: (a) businesses which categorised as having elements involving gambling or trading in prohibited items; (b) conventional financial institutions based on interest (usury), including conventional banks and insurance companies; (c) businesses that produce, distribute, and trade non-halal food and drink; (d) businesses that produce, distribute, and/or provide goods or services which could cause damage or be harmful to people or their morale. The details about 
criteria for halal product are also explained in OJK regulation number 35/POJK.04/2017 (OJK, 2017). They include the following categories: (a) non-halal goods or services based on their ingredients (haram li-dzatihi); (b) non-halal goods or services due to reasons other than the ingredients (haram li-ghairihi) in accordance with a fatwa of the DSN-MUI; (c) goods or services which could damage morale; (d) other goods or services which are contrary to Islamic principles based on fatwa issued by the DSN-MUI.

Considering that one type of Sharia mutual funds is a portfolio of selected Islamic stocks, the investment manager has to choose the most suitable stock listed in the Sharia Securities List. The Sharia Security List is updated and announced periodically by the OJK. It has the authority to evaluate and list the companies which produces halal products, based on the OJK's regulation and the fatwa of the DSNMUI. Besides Sharia stock mutual funds, the funds are also placed in some other instruments vehicles, including money market investments, fixed-income investments and other products offered by Sharia mutual funds. The investment manager has to meet Islamic principles by choosing the financial instruments which are categorised as halal products.

\subsection{No Uncertainty (Gharar) and No Element of Gambling (Maisir)}

The third principle of Sharia compliance is no uncertainty (gharar). The products offered to investors must not containing any elements involving speculation. This rule is stated in the fatwa issued by the DSN-MUI number 20/DSN-MUI/IV/2001 (Dewan Syariah Nasional, 2001) which explains that investments in Sharia mutual funds have to be conducted in accordance with the prudential management (ihtiyath), which does not allow for any speculation involving uncertainty (gharar). In addition, OJK regulation number 15/POJK.04/2015 (OJK, 2015a) also stresses that uncertainty and transaction which contain speculation are not in accordance with Islamic principles. Furthermore, this regulation explains that the actions which were considered to be gharar included: (a) najsy, which involves offering the fake product or service; (b) bai al-ma'dum (short selling), the sale of goods that are not yet owned; (c) insider trading, which is the transmission of misleading information or using insider information to obtain prohibited benefit; (d) investment in companies which debts are greater than their capital.

Another Islamic principle for Sharia mutual funds investments is there must be no element of gambling (maisir). It is stated in OJK regulation number 15/POJK.04/2015 (OJK, 2015a) that the investment must comply with this law. The activities that are not permitted include games involving gambling and risk trading, which has elements of gambling.

\subsection{Conducting an Economic Activities (Mu'amalah) based on Islamic Principles}


The fatwa issued by the DSN-MUI number 126/DSN-MUI/VII/2019 about wakalah bi al-istitsmar (Dewan Syariah Nasional, 2019) explained that Islam strongly encourages Muslims to conduct their economic activities (mu'amalah) in the right way, and prohibits the hoarding of goods, or keeping unproductive or idle assets (money) because the whole purpose is to enhance social welfare. The fatwa also explaines that economic activities in Islam are carried out based on liking (al-taradi), being fair (al-'adalah) and being beneficial for everyone (laa dharara walaa dhiraar).

Based on the fiqh rule, it is explained that "mu'amalah or conducting economic activities is permissible unless there is an argument which forbids them." Sharia mutual funds are also the investments that are related to the banking industry. Sharia mutual fund investments involve a custodian bank that acts as the third party in the wakalah agreement, therefore it is important to refer to the MUI's fatwa number 1 of 2004 (Majelis Ulama Indonesia, 2004). It regulates and explains the law of mu'amalah for conventional financial institutions. The provision in conducting mu'amalah with conventional financial institutions, according to this fatwa, is as follows: (1) in areas where an office/branch of a Sharia financial institution is available and easily accessible, the transactions with the conventional financial institutions are prohibited, (2) in areas where there is no office/branch of Sharia financial institution, it is permissible to conduct a financial transaction with a conventional financial institution, based on the principle of emergency or dharurat/hajat.

With Sharia mutual fund investments, each investor's funds are generally held, recorded and reported by the custodian bank, e.g. Mandiri Bank (a state-owned bank) in Indonesia. However, there is limited numbers of Sharia bank in Indonesia that is capable of fulfilling the role of a custodian bank and only one of them (i.e. Bank Syariah Mandiri) has the authority to act as such. While it refers to this fatwa, mu'amalah with the conventional financial institutions can only be used in an emergency, such as when Sharia financial institutions are unavailable. Therefore, the availability of Sharia custodian bank in supporting the transaction related to the financial market investments, has to be considered, in order to satisfy Islamic principles.

When conducting economic activities, Islam states people should avoid harmful actions (mudharat). It is stated in the fatwa of the DSN-MUI number 126/DSNMUI/VIII/2019 (Dewan Syariah Nasional, 2019) which mentioned that "Avoiding damage/danger (mafsadat) must take precedence over bringing benefit." The criteria for business activities which violate Islamic principles are also mentioned in the fatwa issued by the DSN-MUI number 40/DSN-MUI/X/2003 (Dewan Syariah Nasional, 2003) and OJK regulation number 35/POJK.04/2017 (OJK, 2017). These explain which types of businesses are not in accordance with Islamic principles, including the producers, distributors and/or providers of goods or services which could damage and be harmful to morale. In addition, they also state that business 
activities that which lead to misleading information are also considered to violate Islamic principles.

\subsection{Margin Trading, Short Selling, Hoarding (Ikhtirar) and Insider Trading are prohibited}

Margin trading is defined as trading Sharia securities with an interest-based loan facility for the settlement of the Sharia securities. OJK regulation number 15/POJK.04 /2015 (OJK, 2015b) refers to this practice. Based on this regulation, it is also known that margin trading of Islamic securities contains elements of interest (riba), therefore margin trading is considered to violate Islamic principles.

The fatwa issued by the DSN-MUI number 40/DSN-MUI/X/2003 (Dewan Syariah Nasional, 2003) and number 20/DSN-MUI/IV/2001 (Dewan Syariah Nasional, 2001) state that short selling is known as bai'al-ma'dum. Based on these fatwa, short selling (bai'al-ma'dum) is defined as selling goods or Sharia securities that are not yet owned and this is not permitted. In OJK regulation number 15/POJK.04/2015 (OJK, 2015a), hoarding (ikhtirar) is defined as buying or collecting Sharia securities to make a profit from the changes in the price of Sharia securities, due to the demand created for them.

Insider trading is regulated by DSN-MUI's fatwa number 40/DSN-MUI/X/2003 (Dewan Syariah Nasional, 2003) and number 20/DSN-MUI/IV/2001 (Dewan Syariah Nasional, 2001). Based on these fatwa, insider trading is defined as disseminating misleading information or using inside information to gain profits from prohibited transactions. This practice violates Islamic principles.

\subsection{The Compensation (Ujrah) is Allowed}

Sharia mutual fund investors and their investment managers engage in an Islamic agreement which is called wakalah. An investment manager acts as the party who has the authority to manage the investors' funds. Based on the DSN-MUI's fatwa number 126/DSN-MUI/VII/2019 (Dewan Syariah Nasional, 2019), ujrah is defined as compensation that has to be paid for the service which is performed by representatives in wakalah bi al-ujrah. Due to the service which is provided by the investment manager, so it is permitted in Islamic law that they receive ujrah or fee in the wakalah agreement.

\section{Conclusion and Recommendations}

This study describes the elements of Sharia compliance, which consist of Islamic principles including non-interest transactions, providing halal products, no uncertainty, and no element of gambling while the fatwa issued by the DSN-MUI reinforced that margin trading, short selling, hoarding (ikhtirar), and insider trading are prohibited. Concerning Sharia mutual fund investments, the type of financial 
activity is conducted under Islamic law or mu'amalah. Investors and investment managers were engaged, based on a wakalah agreement, and it is permitted for the investment managers to receive compensation (ujrah) for the service in they provide managing each investor's funds.

This study finds that only one of Sharia bank has the role and authority to act as the custodian bank for Sharia mutual funds investment. This finding implies that the policymakers need to consider the availability and accessibility of a Sharia bank to act as a custodian bank because, based on the fatwa issued by the MUI, it is prohibited to conduct any financial activity with conventional financial institutions in the area where a Sharia financial institution is available and easily accessible.

We note some elements of Sharia compliance are based on secondary data which are collected from the GoI's published documents and some scholarly papers related to Sharia compliance, therefore this study suggests to explore Sharia compliance using another approach, which could be applied in a future qualitative study.

\section{References:}

Bernanthos, B. 2018. Employees' Performance in Islamic Banking. European Research Studies Journal, 21(1), 31-42.

Dakhoir, A. 2019. The fatwa authorities of National Syaria Council of Majelis Ulama Indonesia in supporting the principle of syariah compliance. Journal of Legal, Ethical and Regulatory Issues, 22(1), 1-5.

DeLorenzo, Y.T. 2000. Shariah supervision of Islamic mutual funds. Paper presented at the 4th Annual Harvard Forum on Islamic Finance.

Dewan Syariah Nasional. 2001. Fatwa Dewan Syariah Nasional Nomor 20/DSNMUI/IV/2001 tentang Pedoman Pelaksanaan Investasi untuk Reksa Dana Syari'ah. https://dsnmui.or.id/kategori/fatwa/page/11/.

Dewan Syariah Nasional. 2003. Fatwa Dewan Syariah Nasional Nomor 40/DSNMUI/X/2003 tentang Pasar Modal dan Pedoman Umum Penerapan Prinsip Syariah di Bidang Pasar Modal. https://dsnmui.or.id/kategori/fatwa/page/9/.

Dewan Syariah Nasional. 2019. Fatwa Dewan Syariah Nasional Nomor 126/DSNMUI/VII/2019 tentang Akad Wakalah Bi Al-Istitsmar. https://dsnmui.or.id/kategori/fatwa/.

Hussain, H.I., Shamsudin, M.F., Salehuddin. S. and Jabarullah, N.H. 2018. Debt Maturity and Shariah Compliance: Evidence from Malaysian Panel Data. European Research Studies Journal, 21(1), 176-186.

Jaballah, J., Peillex, J., Weill, L. 2018. Is Being Sharia compliant worth it? Economy Modelling, 72, 353-362.

Majelis Ulama Indonesia. 2004. Fatwa Majelis Ulama Indonesia Nomor 1 Tahun 2004 tentang Bunga (Interest/Faidah). http://mui.or.id/wp-content/uploads/files/fatwa/32.Bunga-InterestFaidah.pdf.

Nurhisam, L. 2016. Kepatuhan syariah (Sharia compliance) dalam industri keuangan syariah. Ar Raniry: International Journal of Islamic Studies, 3(1), 23-44.

Otoritas Jasa Keuangan. 2015a. Peraturan Otoritas Jasa Keuangan Nomor 15/POJK.04/2015 tentang Penerapan Prinsip Syariah di Pasar Modal. 
https://www.ojk.go.id/id/regulasi/Pages/POJK-tentang-Penerapan-Prinsip-Syariah-diPasar-Modal.aspx.

Otoritas Jasa Keuangan. 2015b. Peraturan Otoritas Jasa Keuangan Nomor 19/POJK.04/2015 tentang Penerbitan dan Persyaratan Reksa Dana Syariah. https://www.ojk.go.id/id/regulasi/Pages/POJK-tentang-Penerbitan-dan-PersyaratanReksa-Dana-Syariah.aspx.

Otoritas Jasa Keuangan. 2017. Peraturan Otoritas Jasa Keuangan Nomor 35/POJK.04/2017 tentang Kriteria dan penerbitan Daftar Efek Syariah. https://www.ojk.go.id/id/regulasi/Pages/Kriteria-dan-Penerbitan-Daftar-Efek-Syariahaspx.

Ritchie, J., Lewis, J., Nicholls, C.M., Ormston, R. 2013. Qualitative research practice: A guide for social science students and researchers. Sage.

Suryanto, T., Thalassinos, I.E. 2017. Cultural Ethics and Consequences in Whistle-Blowing among Professional Accountants: An Empirical Analysis. Journal of Applied Economic Sciences, 6(52), 1725-1731.

Widyastuti, U., Febrian, E., Sutisna, Fitrijanti, T. 2019. Factors explaining the market discipline of sharia mutual funds from a behavioural finance perspective: a theoretical approach. International Journal of Economics and Business Administration, 7(3), 198212. 